\title{
BIRDS OF ST. CROIX
}

\author{
By Harry A. Beattry, \\ Estate Constitution Hill, St. Croix, V. I., U. S. A.
}

[NOTE: In response to an urgent request, Mr. Beatty has prepared this valuable paper giving the result of his years of study of the birds of St. Croix. Many species are here recorded for the first time from that island, and one (the Canadian Warbler) is new to the known avifauna of the West Indies. While I was in St. Croix I examined the greater part of Mr. Beatty's collections of birds and eggs. I have somewhat revised the original manuseript as given to me by Mr. Beatty by changing the order in which the birds are listed, inserting the scientific names, and making other slight changes of an editorial nature. S. T. Danforth.]

St. Croix, the largest of the American Virgin Islands, is twentyone miles long, varying in width from one to four and a half miles, and is traver'sed by a broken range of hills from east to west, attaining its greates height in Mount Eagle, with an altitude of 1,165 feet.

The eastern end of the range is overgrown with brush and cacti, and many of the valleys are now dense jungles. The western portion of the range rises abruptly from the coast line on the north, hence there are many deep valleys clothed in verdant jungles, with an abundance of fruit trees. The south side of the island is mostly fiat land, devoted principally to the cultivation of sugar cane.

The ponds include: Kager's, Coakley Bay, South Gate, Rust-optwist, and Two Williams; the amount of water in them depends on the rainfall and the accumulation off of the hills, and as there are no running streams to offset the tremendous loss by evaporation they are often dry for many months in the year, which affects the water fowl population. Narrow strips of land, from 100 to 200 feet in width, overgrown with manchineel, sea grape, acacia and nichol vines, separate the ponds, with their fringe of mangrove's and brackish water, from the sea.

The mangrove-fringed lagoons, including Krause, the Salt Pond, Billy French, and Hammer Pond, are all separated by narrow strips of land from the sea, with which they are directly connected by two or three small channels.

In conclu'sion I wish to commend my pal George Seaman, who is now residing on the island, for his friendship and the interest he manifested in the accumulation of data on the birds of St. Croix. 


\section{PODILYMBUS PODICEPS ANTILLARUM (Bangs). Antillean Grebe.}

I observed four on October 25, 1922 at Krause Lagoon. George Seaman saw four on December 10, 1923 on Krause Lagoon, and collected one specimen; saw two Jan. 20, 1924, on Two Williams Pond, and collected one.

2. PELECANUS OCCIDENTALIS OCCIDENTALIS (Linné). Brown Pelican. Local Name, "Pelican".

Resident. Common. Breeds in February and March on the mainland and Buck Island. March 10, 1924, I collected a set of two eggs, $3.08 \times 1.94^{\prime \prime}$; and $3.12 \times 1.88^{\prime \prime}$ white chalky shells, nest stained.

3. FREGATA MAGNIFICENS (Mathews). Man-o-War Bird. Local Names "Weather Bird" and Hurricane Bird.

Arrives early in February, and remains until July. I have never found them nesting, although they are found in large numbers on Buck Island.

4. $A R D E A$ HERODIAS ADOXA (Oberholser). West Indian Great Blue Heron. Local Name, "Blue Gaulin".

Uncommon. Usually seen on the open pastures around Krause Lagoon and on the sea coast, in the shallows. Although I am certain that they nest on the island I have been unable to locate nests or young birds.

5. CASMERODIUS ALBUS EGRETTA (Gmelin). Egret. Local Name, "White Gaulin".

Uncommon. After many years of persistent searching my efforts were finally rewarded on March 30, 1924, when I found the nesting site of the colony. Along with other species, there were two nests of this species situated near the top of a large clump of mangroves which grew far out in the least inviting part of Krause Lagoon. One nest was empty, and the other contained two downy white chicks and one addled egg, which I handled very carefully, and is now in my collection. It measures $2.22 \times 1.63^{\prime \prime}$, and is pale greenish blue in color. .

6. EGRETTA THULA THULA (Molina). Snowy Egret. Local Name, "White Gaulin".

Resident, and increasing in numbers; at present not uncommon. I collected two sets of eggs on March 30, 1924; one set of three, 
$1.75 \times 1.28^{\prime \prime}, 1.75 \times 1.28^{\prime \prime}, 1.72 \times 1.31^{\prime \prime}$; one set of two egg's, $1.59 \times 1.25^{\prime \prime}$ and $1.69 \times 1.25^{\prime \prime}$. Nests in colony at Krause Lagoon, of coarse sticks loosely put together to form a platform. Eggs pale greenish blue.

7. FLORIDA CAERULEA CAERULESCENS (Latham). Southern Little Blue Heron. Loeal Name "Blue Gaulin".

Resident, and increasing in numbers; at present not uncommon. F'ound them breeding in colony at Krause Lagoon with other species. A set of three eggs collected March 30, 1924, were greenish blue, $1.75 \times 1.31^{\prime \prime}, 1.75 \times 1.31^{\prime \prime}$, and $1.78 \times 1.38^{\prime \prime}$. Nest a frail platform of coarse sticks.

8. BUTORIDES VIRESCENS MACULATUS (Boddaert). West Indian Little Green Heron. Local Name, "Least Pond Gaulin".

Resident. Very common. I have found nests in almost every month of the year. I collected a set of three eggs August 4, 1919, $1.50 \times 1.13^{\prime \prime}, 1.50 \times 1.13^{\prime \prime}$, and $1.59 \times 1.13^{\prime \prime}$, pale greenish in color; nest a frail platform of coarse sticks placed twenty-five feet up on the horizontal branch of a mahogany tree on Constitution Hill, far from water.

9. NYCTICORAX NYCTICORAX NAEVIUS (Boddaert). Black Crowned Night Heron.

March 20, 1922, I shot a male on South Gate Pond.

10. NYCTANASSA VIOLACEA VIOLACEA (Linné). Yellow Crowned Night Heron. Local "Night Gaulin".

Resident; a very common species. A set of three eggs taken May 4, 1922, was greenish blue in color, and measured $2.16 \times 1.50^{\prime \prime}$, $2.16 \times 1.50^{\prime \prime}$, and $2.03 \times 1.47^{\prime \prime}$; ne'st a bulky platform of coarse sticks stituated in a mahogany sapling, seven feet above the ground.

11. DENDROCYGNA ARBOREA (Linné). West Indian Tree Duck.

Resident. Now very rare on the island, where fifteen years ago it was very common, and used to breed.

12. DENDROCYGNA AUTUMNALIS (Linné). Black-bellied Tree Duck.

I collected a male May 18, 1919, on South Gate Pond.

13. MARECA AMERICANA (Gmelin). Baldpate.

George Seaman shot a male Nov. 11, 1921, on Krause Lagoon. 
14. $A N A S$ BOSCHAS BOSCHAS (Linné). Mallard. Pond.

Shot a male in perfect plumage March 14, 1919, on Southgate

15. DAFILA ACUTA TZITZIHOA (Vieillot). Pintail.

Collected a male and female Nov. 5, 1921, on Krause Lagoon.

16. DAFILA BAHAMENSIS BAHAMENSIS (Linné). Bahama Duck. Local Name, "Brass Wing Teal".

Resident, not common. In March and April I have 'seen ducklings of this species on South Gate Pond. No nests or eggs were found by me.

17. QUEREQUEDULA DISCORS (Linné). Blue Winged Teal.

Observed ten on Oct. 5, 1921, and eight on Nov. 24, 1922, on South Gate Pond, and collected four specimens; also ten on January 5, 1923, and thirty on Feb. 10, 1924, on Krause Lagoon, and collected three specimens.

18. ERISMATURA JAMAICENSIS JAMAICENSIS (Gmelin). West Indian Ruddy Duck.

Collected four specimens from a flock of ten Oct. 5, 1922, on South Gate Pond.

19. BUTEO BOREALIS JAMAICENSES (Gmelin). West Indian Red-tailed. Local Name, "Chicken Hawk".

Resident. A few found in isolated pairs over the island, and they seem to maintain their numbers well from year to year considering that many of them are shot. I located a nest on March 3, 1922, constructed of coarse sticks, bulky, with a depression in the center. The two dull white eggs measured $2.22 \times 1.38^{\prime \prime}$, and were ne'st stained krownish. The nest was situated about seventy-five feet up at the top of a "water wood" tree that grew in a heavily wooded locality bear Constitution Hill. February 17, 1924, I examined another nest which was composed of coarse sticks and placed fifty feet up in the crotch of a limb on a mahogany tree near estate La Grange; the two fresh dull white eggs, slightly nest-stained each measured $2.28 \times 1.38^{\prime \prime}$. Both sets are in my collection.

\section{PANDION HALIAËTUS CAROLINENSIS (Gmelin). Osprey.}

Regular winter visitant, not uncommon. May 6 (2); August 13 (2); November 27 (2); March 23 (2); April 9 (2); September 24 (2). Specimens collected. 
21. FALCO COLUMBARIUS COLUMBARIUS (Linné). Pigeon Hawk.

Regular winter visitant. Nov. 5 (4); Nov. 26 (1), near Krause Lagoon. Feb. 23 (1) ; Jan. 1 (1), at Estate La Grange. Two specimens collected.

22. FALCO SPARVERIUS CARIBAEARUM (Gmelin). Antillean Sparrow Hawk. Local Name "Killy-killy".

Resident. Very common, and found on all parts of the island. Nest in holes in trees; breed from February to May. Collecte? set of three fresh egg's May 28, 1919 that were resting on the bare wood at the bottom of a hole two feet deep, in a "Thibet" tree on Estate Constitution Hill. The eggs measured $1.44 \times 1.16^{\prime \prime}$; $1.44 \times 1.16^{\prime \prime} ; 1.41 \times 1.16^{\prime \prime}$; they were straw brown in color very evenly peppered with chocolate and brown specks.

23. COLINUS VIRGINIANUS VIRGINIANUS (Linné). Quail. Local Names "Quail" and "Quail-dle".

Resident. Rapidly decreasing in numbers, and now their range is restricted to the cattle pastures of the south side of the island. I collected a set of ten egg's May 11, 1924, on Estate "Envy".

\section{RALLUS LONGIROSTRIS CARIBAEUS (Ridgway). Caribbean Clapper Rail.}

Resident. Common in the mangroves bordering Krause Lagoon, the only place on the island where they are found. Aug. 27, 1919, I flushed a bird from her nest, hidden in a bed of tall "pond weeds". that grow on the elevations above the water's level. The nest wa's composed of "pond weeds" placed six inches above the ground. The set of seven eggs, which I collected, measured as follows: $1.75 \times 1.19^{\prime \prime} ; 1.75 \times 1.19^{\prime \prime} ; 1.72 \times 1.19^{\prime \prime} ; \quad 1.72 \times 1.19^{\prime \prime}$; $1.69 \times 1.19^{\prime \prime} ; 1.75 \times 1.19^{\prime \prime} 1.72 \times 1.16^{\prime \prime} ;$ glossy cream white color with large blackish and dark spots.

\section{PORZANA CAROLINA (Linné). Sora.}

A regular winter visitant; common on all the ponds, and Krause Lagoon. Jan. 5, 1922, I saw 20 on South Gate Pond; Oct. 22, 1922, 30 on Two Williams Pond; Dec. 10, 1922, 25 on South Gate Pond; Feb. 5, 1923, 25 on Krause Lagoon; Mar. 20, 1923, 25 on Krause Lagoon. Many specimens were collected.

26. GALLINULA CHLOROPUS PORTORICENSIS (Danforth). Antillean Gallinule. Local Name "Waterfowl".

Not an abundant species, but found on all the ponds and lagoons. 
Breeds from March to July. A set of six egg's taken July 22, 1919, measured as follows: Four eggs, $1.81 \times 1.31^{\prime \prime}$; two eggs, $1.79 \times 1.31^{\prime \prime}$. A single rotten egg taken from another nest measured $1.75 \times 1.28^{\prime \prime}$. Nest made of "rushes", shaped into a platform, deeply cupped, and placed two feet above the water among the growing "ru'shes". Eggs glossed creamy white with large and small brown and light brown spots.

27. FULICA AMERICANA GRENADENSIS (Riley). West Indian Coot.

Common on all the ponds and lagoons, where they breed from July to October. Aug. 10, 1919, I took seven eggs from a nest which was composed of coarse sticks forming a platform on a mangrove branch extended on the surface of the water on South Gate. Pond. Eggs measured as follows: 4 eggs, $1.94 \times 1.31^{\prime \prime}$; 3 eggs $1.97 \times 1.31^{\prime \prime}$; dull white with a dusky tint and sprinkled with blackish. (Note: In a letter Mr. Beatty especially calls my attention to the fact that he has never found $F$. caribaea on St. Croix, S. T. D.)

\section{CHARADRIUS NIVOSUS TENUIROSTRIS (Lawrence). Cuban Snowy Plover.}

Migrant. Arrives in April and leaves in September. Occurs in lesser numbers than the Wilson's Plover. I collected three eggs May $25,1921,1.50 \times 1.00^{\prime \prime} ; 1.48 \times 1.00^{\prime \prime} ; 1.48 \times 1.00^{\prime \prime}$, creamy white ground color spotted and scrawled with brown and light brown. Nest a depression in the sand, unlined, among weeds.

29. CHARADRIUS SEMIPALMATUS (Bonaparte). Semipalmated Plover.

Irregular transient visitor. Krause Lagoon, Nov. 11 (6); Sept. 1 (6). Specimens collected.

30. OCTHODROMUS WILSONIUS WILSONIUS (Ord). Wilson's Plover.

Summer resident. Occurs in small numbers on Krause Lagoon, Hammer Pond, and Salt Pond, where they nest on the sandy stretches, depositing their eggs, usually three, in a depression in the sand, sometimes lined with bits of broken shells. Arrive in January, and leave in October. Three eggs taken May 15, 1922, measure $1.50 \times 1.08^{\prime \prime} ; 1.50 \times 1.08^{\prime \prime}$; and $1.44 \times 1.08^{\prime \prime}$, buffy white, spotted and scrawled with brown, light brown, and dusky.

31. OXYECHUS VOCIFERUS VOCIFERUS (Linné). Killdeer.

Jan. 7, 1922 (12); Feb. 15, 1922 (10); in ploughed field on La Grange Estate on both occasions. Three collected. 
32. PLUVIALIS DOMINICUS DOMINICUS (Muller). Golden Plover.

Shot a male out of three observed at Krause Lagoon, Dec. 29, 1921.

33. SQUATAROLA SQUATAROLA CYNOSURAE (Thayer \& Bangs). Black-bellied Plover.

Shot a male out of three seen May 6, 1922. A specimen was collected by George Seaman.

34. ARENARIA INTERPRES MORINELLA (Linné). Ruddy Turnstone.

Regular transient visitor. Observations, Aug. 15 (12); Aug. 13 (20); Nov. 11 (6); Nov. 26 (12); Nov. 29 (50); Jan. 8 (6); Mar. 23 (6); April 14 (12); May 6 (6); May 31 (10). Frequent the seacoast, Krause Lagoon, and Saltpond. Several specimens collected.

35. GALLINAGO DELICATA (Ord). Wilson's Snipe.

Regular transient visitor. Sept. 2 (3); Nov. 26 (40); Mar. 10 (30); Oct. 22 (1); Jan. 1 (25), all at Krause Lagoon. Several specimens collected.

36. PHAEOPUS HUDSONICUS (Latham). Hudsonian Curlew.

Shot a female out of a pair Aug. 13, 1922, at Krause Lagoon.

37. ACTITIS MACULARIA (Linné). Spotted Sandpiper.

Regular transient visitor. Krause Lagoon, Aug. 13 (1); Jan. 8 (4); Sept. 1 (5); Jan. 1 (8). Specimens collected.

38. TRINGA SOLITARIA SOLITARIA (Wilson). Solitary Sandpiper.

Shot a pair on Coakley Bay Pond, Sept. 20, 1919.

39. CATOPTROPHORUS SEMIPALMATUS SEMIPALMATUS (Gmelin). Willet.

Regular transient visitant. Observations, Sept. 1 (12); Nov. 26 (20); Nov. 29 (about 100); Dec. 29 (24); Feb. 10 (10); Apr. 6 (4); May 6 (4); May 22 (6); May 31 (1), Krause Lagoon. Specimens collected.

40. TOTANOS FLAVIPES (Gmelin). Lesser Yellowlegs.

Regular transient visitant. Observations, Krause Lagoon, Aug. 13 (4); Sept. 5 (24); Oct. 1 (20); Nov. 24 (20); Nov. 29 (60); Dec. 29 (15); Mar. 20 (5); May 1 (3); June 1 (50); June $1 \hat{Z}$ (6). Specimens collected. 
41. TOTANUS MELANOLEUCUS (Gmelin). Greater Yellowlegs.

Uncommon transient visitant. Observations, Krause Lagoon, Sept. 4 (25) ; Oct. 22 (4); Nov. 26 (2). Specimens collected.

42. PISOBIA MINUTILLA (Vieillot). Least Sandpiper.

Regular transient visitor. Observations, July 25 (2); Aug. 13 (50); Sept. 5 (24); Sept. 10 (about 100); Nov. 29 (about 100); Dec. 29 (30); Mar. 23 (15); May 6 (about 100). Many specimens collected.

43. PISOBIA MELANOTOS (Vieillot). Pectoral Sandpiper.

Oct. 1 (12); Nov. 2 on pasture land after heavy rains, near Two Williams Pond. Four specimens collected.

44. LIMNODROMUS GRISEUS GRISEUS (Gmelin). Dowitcher.

Collected two specimens from a flock of ten, Dec. 11, 1921, Krause Lagoon.

45. EREUNETES PUSILLUS (Linné). Semipalmated Sandpiper.

Regular transient visitor. Observations, Sept. 1 (25); Sept. 10 (50); Nov. 24 (10); Nov. 29 (about 100); Dec. 29 (30); Jan. 8 (2); Mar. 23 (10). Frequent's the same places as the Least Sandpipers, and often found in the same flocks.

46. LIMOSA FEDOA (Linné). Marbled Godwit.

Shot a female out of a pair, Nov. 11, 1921, at Krause Lagoon.

47. TRINGA CANUTUS (Linné). Knot.

Shot a male on Krause Lagoon, Dec. 11, 1921.

48. HIMANTOPUS MEXICANUS (Müller). Black Necked Stilt. Local Name, "Red-Shank".

Small numbers were found nesting in May and June on Krause Lagoon and Rust-op-twist Pond. Arriving in March they raise their brood, and depart in September. I collected three eggs June 14, 1921. Nest a hollow in the 'sand, four feet from the water's edge scantily lined with broken pieces of sticks. Eggs measured $1.72 \times 1.16^{\prime \prime} ; 1.72 \times 1.16^{\prime \prime}$; and $1.74 \times 1.16^{\prime \prime}$; buffy clay color heavily spotted with dusky and blackish brown.

49. LARUS ATRICILLA ATRICILLA (Linné). Laughing Gull. Local Names, "Sea-gull", and "Booby"'.

Arrive about April in small numbers, and stay until the early part of September. A few birds apparently breed on Krau'se La- 
goon. I observed immature birds in August, but found no nests with eggs.

50. STERNA DOUGALLII DOUGALLII (Montagu). Roseate Tern. Local Name, "Sea-gull".

Occurs in small numbers, rarely in cocks of from six to ten birds, from March to October. I observed immature bird's in August on Krause Lagoon. They also breed on Bank Island. No eggs collected.

51. STERNA FUSCATA FUSCATA (Linné). Sooty Tern.

I shot a male on the rocks at Hams Bluff, March 20, 1924.

52. STERNA ALBIFRONS ANTILLARUM (Lesson). Least Tern. Local Name "Sea-swallow".

Arrive in April and depart in September. A colony of about 150 birds breeds on the sandy flats of Krau'se Lagoon and another of about the same size at the Salt Pond. I collected a set of two eggs June 20, 1919, both the same size $1.28 \times .94^{\prime \prime}$; grayish white with large blackish spots. Nest a depression in the sand, unlined.

53. THALASSEUS MAXIMUS MAXIMUS (Boddaert). Royal Tern.

Regular visitant. March 5 (3); May 22 (3); Sept. 1 (2); Sept. 20 (8); Sept. 24 (4); Oct. 1 (50); Oct. 6 (6); Nov. 22 (10); Nov. 27 (3); Feb. 10 (2). No nesting records. Specimens collected.

54. COLUMBA LEUCOCEPHALA (Linné). White Crowned Pigeon. Local Names, "Blue Pigeon", and "White-head".

Arriving in March they scatter over the island to feed until May and June, when they gather in countless numbers on Green Quay islet to breed. They build their frail nests of sticks so close together that it is impossible to take a step for fear of destroying eggs and Young. A set of two glossy white eggs measured $1.44 \times 1.09^{\prime \prime} ; 1.50$ $\times 1.09^{\prime \prime}$; taken June 21, 1921. A few birds always stay on the island, keeping to the heavy woods of the North Side.

55. COLUMBA SQUAMOSA (Bonnaterre). Scaled Pigeon. Local Names, "Blue Pigeon", and "Red-head".

Resident. Occur's in small numbers. Confined chiefly to the North Side woods. Breeds in July and August. A nest found July 25, 1921, was a very frail platform of coarse sticks, situated twentyfive feet up on the forked branch of a mahogany tree. I could see plainly the two glossy white eggs through the ne'st from below. Eggs 
measured $1.50 \times 1.03^{\prime \prime} ; 1.47 \times 1.03^{\prime \prime}$. It is not unusual to find nests with only one egg or chick.

56. ZENAIDA ZENAIDA ZENAIDA (Bonaparte). Zenaida Dove. Local Name, "Mountain Dove".

Resident in large numbers, but during May and June greater numbers of birds come to Green Quay islet to breed, ne'sting in company with the White-crowned Pigeons, and leave in July. Resident bird's breed on the mainland.. On May 5, 1919, a set of two glossy white eggs, $1.28 \times .97^{\prime \prime}$ and $1.25 \times .97^{\prime \prime}$, was taken on Estate Constitution Hill. The nest is a platform of sticks, usually better constructed than that of the White Crowned Pigeons.

\section{CHAEMEPELIA PASSERINA TROCHILA (Bonaparte). Porto Rican} Ground Dove. Local Name, "Ground Dove".

Resident. Occurs in large numbers on all parts of the island. Breeds in May and June. A nest of fine sticks, unlined, with two glossy white eggs, $.84 \times .66^{\prime \prime}$, and $.88 \times .66^{\prime \prime}$, was found June 14, 1921, situated four feet above the ground on the branch of an acacia.

58. OREOPELEIA MYSTACEA MYSTACEA (Temminck). Bridled Quail Dove. Local Names, "Partridge", and "Wood Dove".

Resident. Once a common bird in the heavy woods of the North Side, but now close to extinction. Sept. 10, 1923, I shot an immature bird which had not been long out of the nest, as the soft bill, broad at the base, indicated, and I believe it flushed from a nest a's I forced. my way through the heavy underbrush. The mongoose is solely responsible for the decrease in the numbers of this species.

59. COCCYZUS MINOR TERES (Peters). Mangrove Cuckoo. Local Names, "Cat Bird" and "Cow Bird".

An abundant species, having a general distribution. Their nestsare difficult to locate. A set of two pale sky blue eggs collected Feb. 10, 1922, measured $1.25 \times .94^{\prime \prime}$; and $1.19 \times .94^{\prime \prime}$. I waited ten days before taking these eggs to give the female time to deposit others, but apparently this was the full complement. The nest was a bulky platform of coarse sticks placed eight feet above the ground. on the horizontal branch of a "ginger thomas" tree.

60. CROTOPHAGA ANI (Linné). Ani. Local Name, "Black Witch".

Resident. Common on all parts of the island except the heavily wooded areas. It's breeding habits are irregular. A set of seven eggs was collected Nov. 17, 1921 from a nest occupied by a single- 
pair of birds. The nest was well constructed of coarse sticks, having a deep, unlined cavity. The egg's were greenish blue in color, with a white chally coating, scratched in several places.

\section{GYMMASIO NDDIPES NEWTONI (Lawrence). Newton's Owl. Local Name, "Kookoo bird".}

Newton's Owl. Local name, "Kookoo bird". I have come to the conclusion that this species is now extinct on the island, after years of fruitless efforts on my part to obtain, or even hear, a single specimen. Thirty years ago it must have been a fairly common bird in its restricted area, the heavily wooded areas of the North Side. All the native "old-timers" who have been living in that vicinity all their lives are familiar with the little "kookoo-bird", as it is known to them. In 1923 I was taken to a very old "thibet tree" which was nothing more than a living shell. About twenty feet up there was a large hole in the side. Pointing at the hole, the aged cattle herder, who is still alive and living in the "village" at Little Fountain Estate, where he was born, said to me, "A pair of kookoo-birds used to live in that hole, and I used to hear them bawling in the night." Then I asked him what the "bawling" sounded like, and he anwered "koo-koo, koo-koo", hence the local name. Then I enquired, "how many years, about, since you remember seeing or hearing the last koo-koo bird?" Taking a hold of his heavy jaw with his roughened hands, he was thoughtful a moment, then calmly answered, "Boss, it must be done gone over eight or ten years." I passed the word along among the North Side Villagers, that the person who could give me information leading to the capture of a "koo-koo bird" would be rewarded with five dollars. The offer still stands, but no owl's.

\section{ANTROSTOMUS CAROLINENSIS (Gmelin). Chuck-will's-widow.}

Regular winter visitant. Nov. 9 (1); Nov. 12 (2), at Constituiion Hill Estate. Jan. 1 (1); Jan. 16 (2), in the North Side Woods. Two specimens collected. Uncommon.

63. ORTHORHYNCHUS EXILIS EXILIS (Gmelin). Gilt Crested Hummingbird. Local Name "Doctor Bird".

Resident. Not so common as the larger species, and prefers the dense undergrowth of woods to the open country. A nest, made of cotton adorned with lichens, was taken Feb. 25, 1920, and was placed two feet above the ground in the crotch of a mahogany seedling. The two white eggs measured $.44 \times .31^{\prime \prime}$, and $.50 \times .31^{\prime \prime}$. 
64. SERICOTES HOLOSERICEUS HOLOSERICEUS (Linné). Blue-breasted Hummingbird. Local Name, "Doctor Bird".

Re'sident, found everywhere, and on the neighboring islets. A nest with two white eggs was taken July 1, 1929 from a mahogany tree. The nest was made of cotton adorned on the outside with lichens. It was placed eight feet up, at the crotch of small horizontal branch. Eggs $.54 \times .41^{\prime \prime}$, and $.56 \times .41^{\prime \prime}$.

65. STREPTOCERYLE ALCYON ALCYON (Linné). Belted Kingfisher.

Regular winter visitant. Sept. 10 (1); Oct. 9 (4); Nov. 27 (6); Dec. 18 (6); Jan. 1 (2); Feb. 25 (1); Mar. 30 (4); Apr. 9 (3); May 1 (1). Frequents all the lagoons and pond's on the islands.

66. SPHYRAPICUS VARIUS VARIUS (Linné). Yellow-bellied Sapsucker.

Jan. 3, 1924, I shot a female from the branch of a "giant thibet" tree on La Grange Estate.

67. TYRANNUS DOMINICENSIS DOMINICENSIS (Gmelin). Gray Kingbird. Local Name, "Chichery".

Resident. A very common species, also found on neighboring islets. Breeds in May and June. Aug. 25, 1921, I took a set of three eggs, $1.08 \times .78^{\prime \prime} ; 1.08 \times .78^{\prime \prime}$; and $1.05 \times .78^{\prime \prime}$, from a nest which was constructed of fine sticks, deeply cupped and lined with rootlets, placed five feet up, on the branch of an acacia. The eggs were light salmon red, with large and small spots of deep reddish brown and brown, wreathed around the larger end.

\section{ELAENIA MARTINICA RIISII (Sclater). Riise's Elaenia.}

Resident. Increasing rapidly, now common. Ranges over the island and two neighboring islet's. A nest found March 17, 1922, contained two eggs, $.78 \times .63^{\prime \prime}$, and $.81 \times .63^{\prime \prime}$, salmon with lilac and brownish spots, wreathed around the larger end. The nest was $a$ frail platform of fine dry twigs, not lined, placed seven feet up on a bed of vines which draped over the top of a sapling.

69. HIRUNTO ERYTHROGASTER (Boddaert). Barn Swallow.

Regular transient visitor. Aug. 27 (40); Sept. 1 (12); Sept. 10 (60); Oct. 21 (24); Feb. 29 (30); March 30 (15); May 5 (50); June 5 (24); June 10 (1). Ranges over the island. Specimens collected. 
70. PROGNE DOMINICENSIS (Gmelin). Caribbean Martin.

George Seaman observed a pair that remained in the vicinity of Estate Lower Love during 1917 and 1918, and evidently nested in a hole in the factory's smokestack. From March to July, 1923, I observed two pairs flying about the smokestack of the Bethlehem sugar factory, and I believe they nested in one of the draught holes 75 feet up.

71. MIMUS POLYGLOTTOS ORPHEUS (Linné). Jamaican Mockingbird.

Resident. They are increasing rapidly. Apr. 21, 1919, I collected a set of four eggs, $1.00 \times .75^{\prime \prime} ; 1.00 \times .75^{\prime \prime} ; .97 \times .75^{\prime \prime} ; .97$ $\times .75^{\prime \prime}$ pale bluish green heavily spotted with chocolate and brown, wreathed around the larger end. The nest was composed of coarse sticks lined with rootlets, placed two and a half feet above the ground in an acacia.

72. MARGAROPS FUSCATUS FUSCATUS (Vieillot). Pearly Eyed Thrasher. Local Names, "Thrush" and "Sour-sap Bird".

Re'sident. Very common among the "fruit gardens". June 15, 1921, I surprised a female on her nest, which was constructed of coarse sticks, scantily lined with rootlets, and placed at the bottom of a hole in an alligator pear tree. The three eggs measured $1.30 \times$ $88^{\prime \prime} ; 1.32 \times .88^{\prime \prime}$, and $1.30 \times .88^{\prime \prime}$, and were spotle'ss glossy deep sea blue.

73. VIREO OLIVACEUS OLIVACEUS (Linné). Jamaican Vireo. Local Names, "John-chew-it", and "Greenlet".

Very common summer resident, also found on neighboring islets. They leave in August, returning in December and January, and nest in June. June 11, 1921, I found a nest suspended from the forked branch of a "turpentine" tree, twelve feet above the ground. It was made of soft grasses and cotton. The three eggs were all of the same size $\left(.88 \times .63^{\prime \prime}\right)$, and were white with fine blackish spots, wreathed around the larger end.

74. COEREBA NEWTONI (Baird). St. Croix Honey Creeper. Local Name, "Yellow-breast".

Resident. Very common, ranging from seacoast to heavy woods. The breeding season is irregular. A nest, examined Sept. 30, 1921, was made of soft grasses and cotton, unlined, and situated four feet up in a sweet lime hedge; it was domed, with the entrance at the 
side. The three eggs were all the same size $\left(.69 \times .50^{\prime \prime}\right)$, and were white with a salmon tint, finely sprinkled with brown and chocolate.

75. MNIOTILTA VARIA (Linné). Black and White Warbler.

Regular winter visitant. Sept. 10 (4); Oct. 6 (8); Oct. 8 (6); Jan. 1; Jan. 6 (3). Not common, and keep to wooded localities. Specimens collected.

76. COMPSOTHLYPIS AMERICANA PUSILLA (Wilson). Northern Parula Warbler.

Regular winter visitant. Sept. 30 (4); Nov. 6 (12); Dec. 30 (20); Jan. 1 (25); Apr. 1 (30); Apr. 23 (30); Apr. 28 (1); Apr. 30 (10). Very common. Found in the woods, but more common in the sage brush. Specimens collected.

77. DENDROICA TIGRINA (Gmelin). Cape May Warbler.

Regular winter visitant. Sept. 8 (1); Nov. 14 (4); Dec. 11 (4) ; Dec. 30 (2); Jan. 1 (8); Feb. 10 (1); Feb. 23 (4); Apr. 19 (1). Uncommon. All these observations were made around Constitution Hill estate, where the birds kept to the open. Specimens collected.

78. DENDROICA PETECHIA CRUCIANA (Sundevall). Golden Warbler. Local Name, "Canary".

Resident. Rarely met with in wooded areas, preferring the open brush lands and mangrove bordered ponds and lagoons. Nests in May. A set of three eggs taken May 13, 1919, was white, with a greenish tint, spotted with blackish and gray, and wreathed around the larger end. The eggs measured $.72 \times .56^{\prime \prime} ; .75 \times .56^{\prime \prime}$ and $.75 \times$ $.56^{\prime \prime}$ The nest was made of grass and lined with softer grasses, deeply cupped. It was placed three feet up in a "sage" bush.

79. DENDROICA VIRENS VIRENS (Gmelin). Black Throated Green Warbler.

Collected a male and female, Oct. 18, 1919, which were feeding on small green and brown caterpillars on a big "flamboyant" tree on Constitution Hill.

80. DENDROICA DISCOLOR (Vieillot). Prairie Warbler.

Regular winter visitant. Sept. 1 (10); Sept. 7 (25); Dec. 30 (1) ; Jan. 1 (20); Apr. 1 (30); Apr. 23 (25). Common. Found in the woods, but more abundant in the sage brush and open country. Specimens collected. 
81. DENDROICA PALMARUM PALMARUM (Gmelin). Palm Warbler.

Regular winter visitant; common. Oct. 6 (10); Oct. 16 (1); Oct. 20 (4); Jan. 1 (20); Feb. 23 (1); Apr. 30 (1). Confine themselves to the open country.

82. SEIURUS NOVEBORACENSIS NOVEBORACENSIS (Gmelin). Water-thrush.

Regular winter visitant. Sept. 1 (4); Sept. 5 (6); Sept. 18 (10); Nov. 24 (20); Jan. 1 (15); Mar. 20 (10); Apr. 14 (10). Common along streams, ponds and lagoons. Specimens collected.

83. SEIERUS AUROCAPILLUS AUROCAPILLUS (Linné). Ovenbird.

Regular winter visitant. Sept. 15 (4); Dec. 30 (20); Jan. 1 (20). Common in the woods.

84. WILSONIA CANADENSIS (Linné). Canadian Warbler.

Feb. 17, 1924, I startled a cock of small birds that were feeding among the scrub mangroves bordering the Salt Pond. Following them for quite a distance I finally succeeded in obtaining a male which was in perfect plumage. There were about ten altogether.

\section{SETOPHAGA RUTICILLA (Linné). Redstart.}

Regular winter visitant. Sept. 1 (6); Sept. 7 (4); Dec. 30 (3); Jan. 6 (5); Apr. 1 (1); Apr. 23 (15). Common in the woods, seldom seen in the open country. Specimens collected.

86. HOLOQUISCALUS NIGER BRACHYPTERUS (Cassin). (Lawrence). Porto Rico Blackbird.

Introduced from Porto Rico about 1917 at the "Whim" Estate, where they appeared to be doing very well, nesting in the large "thibet" trees around the proprietor's mansion. Nov. 10, 1919, a pair had wandered as far as estate Constitution Hill.

\section{PIRANGA ERYTHROMELAS (Vieillot). Searlet Tanager.}

Shot a male Apr. 20, 1919 which was feeding among the branches of a "turpentine" tree growing on the grounds of Peters Rest Public School. Perfect adult plumage.

88. TIARIS BICOLOR OMISSA (Jardine). Garib Grassquit. Local Names, "Sin-bird", and "Sparrow".

Resident. Common everywhere excepting the heavy woods. Irregular nesting season. A nest and three eggs were collected Sept. 
25, 1923. The domed nest was made of soft grasses, not as compactly woven as the nest of the Honey Creeper, and placed three feet up in an acacia. The entrance was at the side. The eggs measared $.69 \times .53^{\prime \prime} ; .69 \times .53^{\prime \prime}$, and $.72 \times .53^{\prime \prime}$. The ground color was light grayish white, and they were sprinkled with dark brown, especially around the larger end. 